\title{
Transformation of the Educational Process within Online Technologies Implementation in the Period of the Global Crisis
}

\author{
https://doi.org/10.3991/ijet.v16i11.21265 \\ Ganna Khatser $\left.{ }^{(}\right)$, Maxim Khatser, Liudmyla Bukharina, \\ Yana Dybchynska, Maryna Lysenko \\ Zaporizhzhia National University, Zaporizhzhia, Ukraine \\ anvanneukr.net
}

\begin{abstract}
The COVID-19 pandemic has led to drastic changes in all spheres of life. In terms of education, the pandemic modified the way of teaching and learning. To meet the demands of new circumstances, the priorities shifted towards the implementation of online technology. Thus, the article examines the peculiarities of changes that happened in the educational sphere due to the online technology implementation. It analyzes the positive and negative aspects of this phenomenon. Based on the results of the survey conducted among educators, the article identifies weak points and challenges that should be overcome in the future for the successful operation of educational establishments online. Besides, it studies a material base and tools available for free use for world educational establishments as well as a problem of creating online groups with an optimal number of students. The purpose of the research is a comprehensive study of transformations happening in the educational process due to the application of online technology tools at the world level.
\end{abstract}

Keywords - Educational process, online technology, online learning, online teaching, educational establishment, online platform, face-to-face learning

\section{$1 \quad$ Introduction}

The global education system has been changing drastically for the last decade. The economic development of countries, political situations in the world, integration processes, modernization of the key spheres in world countries, determination to optimize all spheres of people's lives, and save material and human resources have greatly influenced the teaching and learning processes. Ever since the emergence of computers, the Internet, and virtual reality, the global educational system has needed adaptation to the new demands. The spread of a global pandemic COVID-19 has led to the growth of online learning and teaching.

Online learning or distance learning is not brand new "notions." Their history is dated back to the 1960s when the first computer-based program titled PLATO was created and implemented in the University of Illinois and schools in this area [1]. The most detailed and comprehensive study on the implementation of online learning, its 
characteristic features and peculiarities, was conducted by B. Means and her colleagues, who highlighted nine dimensions crucial for the effective process: pacing, modality, pedagogy, "student-instructor" ratio, student and instructor roles online, online assessments and their role, source of feedback, and online communication synchrony [2].

To transform the educational process into a digital form requires the integration of all digital processes that create and maintain the online environment for educational establishments [3]. It helps imply these digital technologies in the most optimal way. At the same time, in his article, C. Hodges and his colleagues claim that it is impossible to compare "well-planned online learning" with online courses, which were offered "in response to a crisis" [4].

Some researchers stated that the transfer from face-to-face to the online educational process was rather smooth and painless for some educational establishments [4], [5]. Educators started using digital learning management systems such as Google Classroom, Moodle, ClassDojo, Skooler, etc.; MOOC platforms such as Canvas, Coursera, EdX, Alison, etc.; and other resources. For example, in Austria, educational establishments used learning platforms Moodle and LMS, and products developed by Google and Microsoft [6], [7]. In China, officials developed a special program for online education during the COVID-19 pandemic [8]. In addition, adherents of online education declare that there is no huge difference in online and offline teaching, and distance learning can be more efficient in some cases [9], [10].

However, many educators and scientists demonstrated concerns about the quality and accessibility of online education. Thus, M. Khadijah and the followers emphasize that online learning has certain limitations due to the specificity of subjects, which are taught online [11]. For example, medical students are unable to learn practical and clinical work. Lecturers can only teach "knowledge components."

Besides, in some cases, teachers cannot assess the level of students' understanding of material provided during online lectures and classes. H. Song and co-authors report that based on his study, most of China educators, including both teachers and principals, cannot guarantee the quality of "web-based learning" [12].

Besides, researchers have identified such challenges of online learning as a lack of communication between teachers and students, poor control of students' actions; poor technical support of the process; too much information, what leads to misunderstanding and some conflicts in scheduling [13], [14], [15].

S. Hrastinski declares that for the effective online learning process, educational establishments and their members should have a clear understanding of the limitations and benefits of synchronous and asynchronous online education [16]. Prominent world researchers initialize considerable scientific discussion regarding fields of application, advantages and disadvantages of online learning as well as selection of appropriate actions to increase efficiency of educational process based on this type of education $[17,18,19]$. The prompt development of online learning is emphasized in the modern environment. It requires additional scientific researches in the sphere.

Thus, the aim of the study is a comprehensive understanding of transformations happening in the educational sphere during the global crisis due to the implementation of online technologies. 
The research is based on such hypotheses:

1. Due to the wide promotion of ICT and its penetration into all spheres of life, world educational establishments are ready for online learning.

2. Online form of education is a universal form, which is appropriate for both big and small groups of students.

3. The implementation of online education demands more time and effort from teachers.

4. Advantages of online education prevail over its disadvantages.

\section{Materials and Methods}

The study has used descriptive research, which was achieved with the implantation of quantitative analysis. To obtain statistical data, participants were asked to fill in an online questionnaire, which included 12 questions. One question was "Your country and city," and the other 11 were designed to elicit information on the topic of the research, namely: types of digital resources that people use in their practice, availability of the school/university platform for online learning, age and quantity of students in groups, challenges and advantages of online learning, and others. The questionnaire was anonymous and voluntary.

The respondents represented a diverse environment and consisted of educators from various parts of the world. Thus, the total number of participants was 91 people, among whom 21 lived and worked in Europe and 70 - in the rest of the world. The geography of the research included such countries as Italy, Spain, The United Kingdom, the Netherlands, France, Turkey, Hungary, Ukraine, Russia, Bulgaria, Iraq, Indonesia, Malaysia, Mexico, and others.

Based on the method of comparison, the study has presented the overall pattern of the changes happening in the teaching process due to the global crisis and their perception by educators.

\section{$3 \quad$ Results}

\subsection{Material and resources base for online education}

The transformation process of education, which engages the active implementation of the Internet, online technology, and global interactive products, has begun gathering pace when the world faced the pandemic challenge and started reorienting the traditional forms of education. This trend has both strengths and weaknesses. One of the rather positive moments is its high level of variability, which enables educators to reach all educational purposes and solve problems depending on demands and circumstances. It creates opportunities to use varied resources meeting the demands of a wide range of students.

In addition, online technologies help introduce, promote, and achieve goals of inclusive education, one of the most crucial tasks in the modern world, by providing 
equal access to means of high-quality education to all children and adults. At the same time, one should clearly understand certain challenges caused by this situation. They are varied ranging from the diversity of choice, the necessity to test programs to additional time for training teachers, and making students get used to new products. The problem is that they are not always detected fast and clearly. For example, countries do not have strict standards on providing online education principles and resources that lead to their individual introduction by every school, college, or university. It makes the task harder and may result in the multi-flooding of the educational environment. In addition, the study has shown that technology is always upgrading and improving. Educators need time and additional efforts to track all updates time to implement them in their teaching process.

At the same time, such a variety of online educational products improves the situation in developing countries and countries with income above average by involving the poorest layers of society into the world's educational process. It is explained by its cheapness and sometimes even free of charge character. Thus, students do not need to spend money and can consume educational products of leading higher education institutions of developed countries without spending material resources and visiting foreign countries. Based on the research conducted before the survey, respondents were asked two questions: 1 . What digital resources do you use in your practice? (multiple answers). 2. Does your educational establishment have its own online platform?

Regarding the first question, the respondents were offered several options: Zoom, Google Hangouts, Google Classroom, Moodle, CiscoWebex meeting, and Other. Based on the answers, the most widespread resources are Zoom (63.7\% of all participants) and Google Classroom (37.4\% of all participants) (Fig. 1). Other digital resources mentioned by teachers are indicated in Table 1 and show that educators prefer using social networks, such as Facebook or Instagram, and messengers, such as WhatsApp, where their students spend much of their time. They create special groups to share materials, to give interactive tasks, and to hold meetings. At the same time, a professional corporate platform designed by Microsoft is taking a leading position. Teachers mentioned its free access, simplicity, and the possibility to unite all resources in a common working space. It increases productivity through fruitful collaboration. 


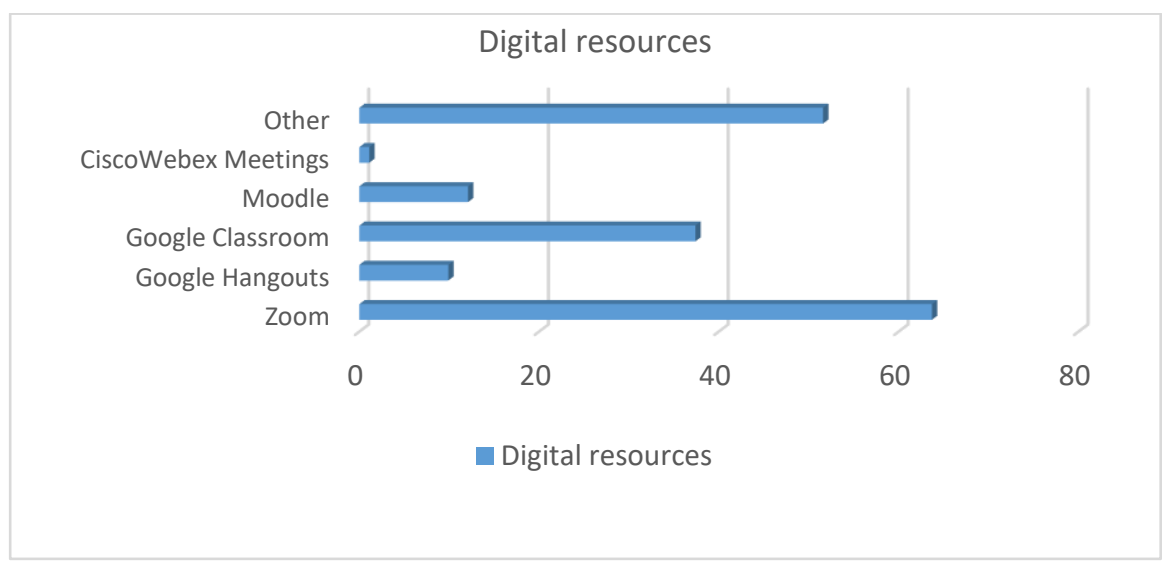

Fig. 1. Dominant online resources

Although Skype is losing its popularity around the world, being shifted by more sophisticated utilities for interaction and communication, it is still rather popular among specialists in the educational environment (Table 1).

Table 1. Other digital resources used by educators during online teaching

\begin{tabular}{|c|c|c|c|}
\hline $\mathbf{N}$ & Title of the resource & Country & $\%$ \\
\hline 1 & Microsoft Teams & $\begin{array}{l}\text { UK, Czech Republic, } \\
\text { Morocco, Curacao, Spain, } \\
\text { Turkey, Bulgaria, Scot- } \\
\text { land }\end{array}$ & 17 \\
\hline 2 & WhatsApp & $\begin{array}{l}\text { Nepal, Spain, Pakistan, } \\
\text { Italy, México, Brazil, } \\
\text { Bulgaria, Indonesia }\end{array}$ & 16.7 \\
\hline 3 & Skype & $\begin{array}{l}\text { Russia, Wales, Spain, } \\
\text { India, The Netherlands }\end{array}$ & 11 \\
\hline 4 & Google meet & Greece & 6 \\
\hline 5 & Quizziz & Malaysia & 5.7 \\
\hline 6 & Padlet & France & 5.5 \\
\hline 7 & Kahoot & France, Malaysia & 5.5 \\
\hline 8 & Discord & Poland, Armenia & 2.9 \\
\hline 9 & Canvas & Russia & 2.7 \\
\hline 10 & Classe Virtuelle & France & 2.7 \\
\hline 11 & Own Website & Ireland & 2.7 \\
\hline 12 & English Discoveries & Indonesia and Surabaya & 2.7 \\
\hline 13 & Viber & Ukraine & 2.7 \\
\hline 14 & Edmondo & Turkey & 2.7 \\
\hline 15 & $\begin{array}{l}\text { Facebook } \\
\text { groups/Instagram }\end{array}$ & Palestine & 2.7 \\
\hline 16 & Kundelik.kz & Kazakhstan & 2.7 \\
\hline 17 & Schoology & Mexico & 2.7 \\
\hline 18 & Learncube & Spain & 2.7 \\
\hline
\end{tabular}


Answering the second question, votes were divided almost equally: $45.1 \%$ of all participants stated that their establishment had its own online platform and $54.9 \%$ told about the lack of such an option. Most of the countries, which provide their educational establishment with online platforms, are developing ones. The developed countries demonstrated a low level of readiness of their institutions in terms of implementing personal platforms and building online process of education on them (Table 2).

Table 2. List of countries with/without own online platforms

\begin{tabular}{|l|l|l|}
\hline \multicolumn{1}{|c|}{ Online platform available } & \multicolumn{1}{c|}{ Online platform is not available } \\
\hline \multirow{4}{*}{ Countries } & El Salvador & Indonesia \\
\cline { 2 - 3 } & Iraq & Spain \\
\cline { 2 - 3 } & Chile & Armenia \\
\cline { 2 - 3 } & Mexico & Argentina \\
\cline { 2 - 3 } & Bulgaria & England \\
\cline { 2 - 3 } & Kazakhstan & Serbia \\
\cline { 2 - 3 } & Taiwan & The Netherlands \\
\cline { 2 - 3 } & Italy & Brazil \\
\cline { 2 - 3 } & Malaysia & Italy \\
\cline { 2 - 3 } & Russia & Algeria \\
\cline { 2 - 3 } & Vietnam & Poland \\
\cline { 2 - 3 } & England & \\
\cline { 2 - 3 } & Poland & \\
\hline
\end{tabular}

As shown in Table. 2, some countries are included in both lists because respondents from different parts of the country gave different answers. Thus, even within one country the situation with the availability of personal online platforms varies depending on various issues (policy of the region, the material basis of the establishment, financing, etc.). Availability of platforms to place tasks and organize meetings with students, a wide range of resources to be used during both the teaching and learning processes, a possibility to choose are important components of online education. However, its quality also has an organizational aspect that should be taken into consideration and analyzed.

\subsection{General organizational issues of online education}

Any educational processes mean a special type of activity in which two parties are engaged, a learner and an educator, and which is aimed at transferring, receiving, and processing knowledge and skills through organized learning and educational activities. Therefore, every educational establishment pays special attention to all components of this process, namely: development of training materials, proper planning of teaching load, selection of pedagogical methods, and organizational forms of training. Besides, specialists also emphasize the importance of students' groups formation. This is particularly true for teaching foreign languages and specialized subjects to divide students based on their level of subject's mastery. In addition, educators consider the average class size. 
Educational establishments address these issues before the academic year starts. They identify the information provided above in the teaching load and responsibilities of teachers who, in their turn, carefully set clear objectives for students. Under normal conditions, teachers have the information on the number of students in their groups, materials, which they are planning to use during lessons, the main textbook, and a base (a school, a college, an institute, a university, etc.) for the implementation of the intended goals.

In the context of a global crisis, which happened at the beginning of 2020 due to the COVID-19 pandemic, the educational process has experienced significant changes. A long-term quarantine, forced closure of enterprises, and educational establishments, as well as people's self-isolation, have led to irreversible processes in all spheres of life. Education is not an exception. Teachers became deprived of both their normal material and technical basis (buildings of schools, colleges, universities, institutes, and universities) and teaching and material resources (hang-outs, additional printed resources for lessons, etc.). The entire process shifted from a physical space to a virtual one. Virtual classes replaced ordinary ones. Teachers and students had to adapt to new terms. Thus, the question arises if the arrangement of the educational process "face-to-face" is suitable for online learning. Is it necessary to make certain adjustments, especially concerning active and productive interaction with the learners? In addition, is this type of education appropriate for all age groups?

Taking into account the information stated above, the questionnaire had the following questions for teachers: How many people are there in your online groups? What are your age groups? The first question had such options: - up to five; - up to 10; - up to 15 ; - up to 20 and more. Based on the respondents' reflections (Fig. 2), the largest number of answers belongs to the last option, the less numerous - to the first.

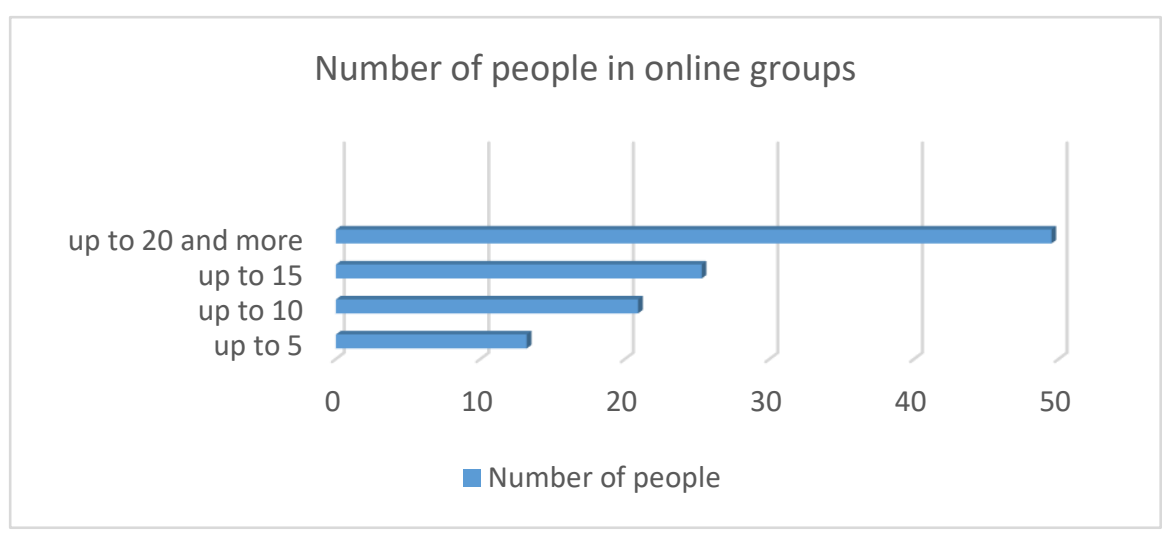

Fig. 2. The quantity of people in online groups

The quantity of people among 5-10 and 10-15 is almost the same. Its differences equal to $4.4 \%$. During the communication, participants mentioned unreadiness to work with large groups online due to challenges of checking the material, organizing online interaction of all groupmates, and reflecting on new topics. At the same time, 
small groups (up to 5 people) are also proved to be not so effective in terms of providing and conducting group tasks. Teachers have time to deliver new material, check the previous; however, it is difficult to implement creative tasks, which require the cooperation of three and more students. Educators who teach in groups of 10-15 people expressed fewer obstacles in working online.

As for the second question, respondents had such options: - 5-8 years; - 8-12 years; 13-17 years; $18-22$ years; $23-30$ years; $30+$ years.

According to Fig. 3, the most numerous age group (53.8\%) is teenagers between 13-17 years old. Then a group with students aged 18-22 takes its position. The last position of a category 5-8 years old is rather predictable and proves the presence of certain problems in the process of teaching younger learners due to their age and the skills to learn. Teachers expressed concerns about the quality of material learning by this category. Such children are not prepared for productive online work and need more time to adapt to the process. They also need assistance from the adults, at least at an early stage.

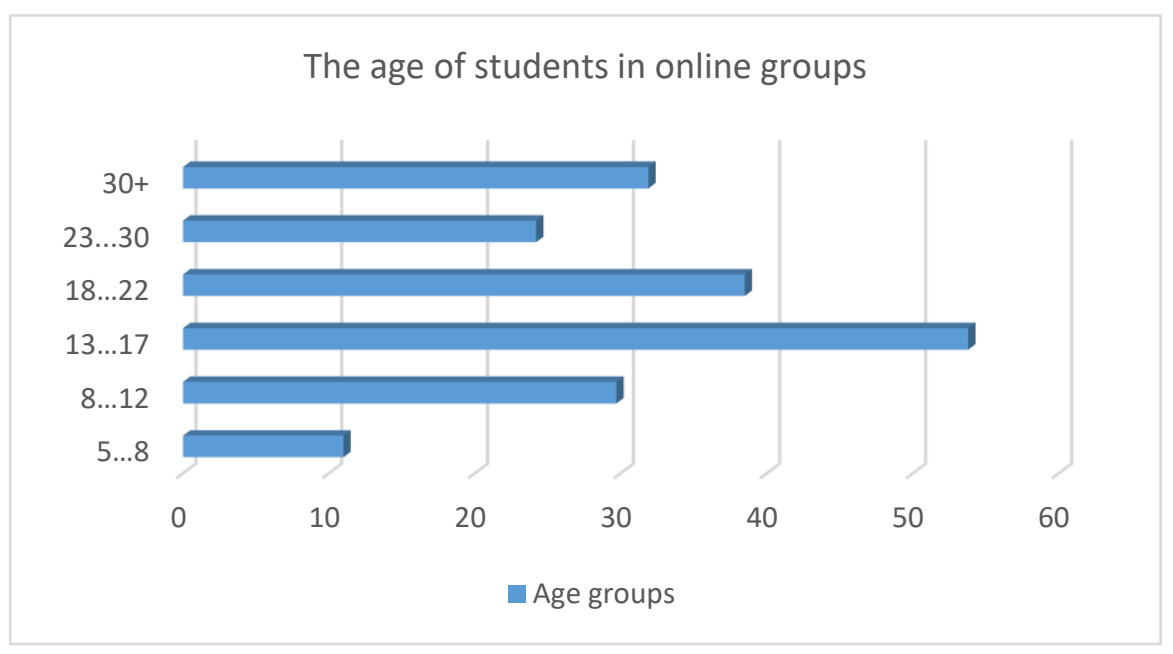

Fig. 3. The age range of students in online groups

Mainly, offline student academic groups were transformed into online without drastic changes. Only some teachers had to divide groups into smaller to organize a lesson more efficiently. However, it was just their initiative, not an official regulation. The prevailing number of teenagers is explained by the active participation of schoolteachers. In addition, they proved to be more flexible and tech-educated comparing to other groups.

Thus, the next step is to analyze the advantages of such types of education for both teachers and students. 


\subsection{Advantages of online educational process}

Under a global pandemic, e-learning seems to be the best solution to maintain the appropriate level of education. It can keep the educational system working and save it from collapsing. Being an agile and dynamic system, online learning has been quickly integrated into professional life. To figure out the benefits of teaching and learning online, educators were asked about the advantages of this type of learning. Several options were developed and offered. According to Fig. 4, the most popular answers were a flexible schedule and the opportunity to use interactive tools. The flexible schedule was indicated by representatives of both developed and developing countries. Thus, no matter where a teacher lives, to what social class belongs, accessibility of online teaching makes it possible to work when it is suitable for him/her and at a pace s/he is used to. When working remotely, a student and a teacher must have an Internet connection and a device to work on. Working in an auditorium, students do not always have the opportunity to work on a PC or a laptop individually. Many educational establishments do not have a sufficient number of computers and other equipment to organize interactive communication between a teacher and students. A pandemic provided such an opportunity.

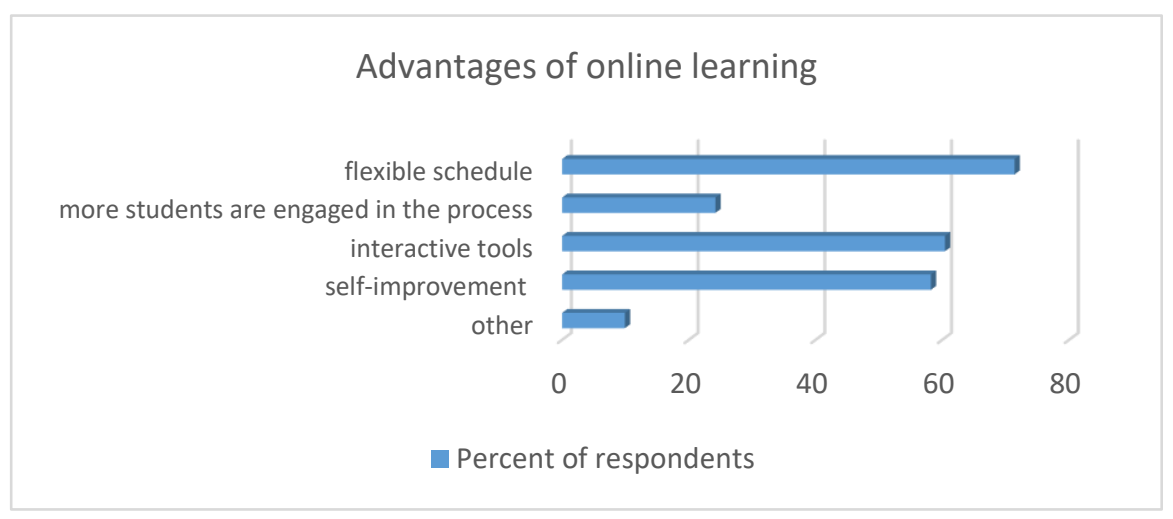

Fig. 4. Advantages of online learning

More than $50 \%$ of respondents chose the "self-improvement" option. Working online demands new skills and abilities. The methodology of working offline does not meet the requirements and specific features of online processes in many cases. Teachers understand the necessity to move further, learn, and search for new techniques. That is why "self-improvement" takes the third position among educators. Less than $30 \%$ of respondents gave their preference to the possibility to engage more students in the process of education. Based on the results of the questionnaire, those, who highlighted this answer, live mostly in developing countries (Ukraine, Indonesia, Mexico, Nepal, Thailand, and others). Ten respondents (less than 10\%) indicated the answer "Other" in their responses. According to the survey, educators find the online system of education more convenient for widening the area of communication and interaction with a global teaching community (extended scope and access to a global community 
of learners sections in the questionnaire). Before the lockdown period, educational establishments, in particular from developing countries, had limited access to global materials, databases, and platforms. Under normal conditions, people have to pay for the opportunity to study and use them in their practice. A global pandemic has changed the situation.

Thus, one of the most popular platforms Zoom has reacted immediately and changed its policy. If earlier, an organizer of a conference could only have 30-40 free minutes, during the raise of a pandemic, Zoom owners removed this limit. It attracted dozens of participants. According to Zoom statistics, the number of daily meetings participants increased drastically from 10 million in December 2019 to more than 300 million in April 2020 [20]. Besides, in winter 2020 approximately 90,000 schools in almost 20 countries worldwide chose this platform for remote education. The same situation is happening with Microsoft's Team. As Vox reported, the usage of this platform and its features such as calls and conferences was up 20\% in March 2020 comparing to February 2020 in China [21]. Respondents also mentioned such positive aspects of distance learning as ICT savvy and less paperwork. Indeed, working online teachers have to use many technological tools and apps. Without an appropriate level of knowledge, it is impossible to conduct full-fledged lectures or practical lessons. Educators highlighted the reduction of paper workload and the shifting of priorities towards online document management. However, some teachers (aged 50+) gave preferences to a paper format of tasks, which should have been photographed and sent as a picture for checking. As well as the above, respondents also wrote about a bigger job market as one of the additional advantages of online learning. Working online makes borders become blurring and participants of the process can find many professional opportunities for self-development and growth. As an example, teachers note professional Facebook groups, such as British Council Teacher Community, Teaching and Coaching Innovation or Teacher Development Webinars, where they share their experience, organize online communication of their students, ask for professional advice, conduct lectures, and other (Fig. 5).
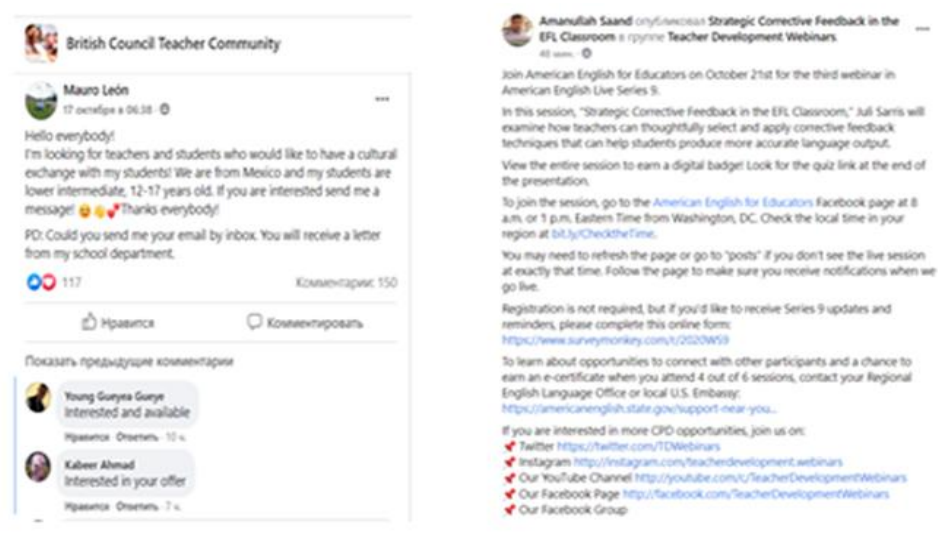

Fig. 5. Examples of messages in online professional groups 
Finally, one respondent defined online learning as "one of the only possibilities." When everyone is on lockdown, it is impossible to continue a normal way of living, working, and studying. People do not have a choice and have to adapt to circumstances. The respondent does not see any sense in complaining about or praising the online way of education. He states that if people want to survive and receive at least minimum standards of a good education, they just have to accept it as a need and a modern reality.

\subsection{Obstacles of online educational process}

Any process has both positive and negative aspects. Thus, when studying online teaching and learning process, respondents were asked several questions related to challenges that they faced; their attitude to the further perspectives of this form of teaching; and the reaction of their students on online learning:

What challenges of online learning can you list based on your experience?

Do you spend more time preparing and checking tasks for online classes in comparison with offline ones?

Would you like to implement such a form of learning in your regular teaching process in the future (after the global pandemic)?

What do your students think about online learning?

Responding to the first question, teachers had several options, including a timeconsuming process; technical issues; slow Internet connection or its absence; computer literacy; self-discipline from students; more work for teachers; little or no face-toface interaction; not all students are active, or a sense of isolation both for teachers and students. According to the survey, one of the biggest hurdles for implementing elearning is the sociocultural problem. Some teachers mentioned radically negative beliefs and attitudes of students towards this type of instruction. If developed countries were prepared enough to switch to online education, developing countries faced a number of problems, including poor Internet connection, a low income of families who cannot afford to buy a laptop, PC, or even a smartphone. Thus, one of the respondents from Ukraine gave an example of a multi-children family, where children had to study online at the same time. Thus, they had to have their individual computers or other devices to be online. However, for this family, it was impossible to buy such a number of devices. The teacher highlighted that it was not a rare occasion and appeared in many countries. In addition, particularly female students who have a good internet connection and their PCs and smartphones refuse to appear online because of religious rules.

According to Fig. 6, for teachers, the biggest challenges are technical aspects of online education (more than $70 \%$ of respondents), problems with the Internet connection (more than $65 \%$ of respondents), and more work to be done during teaching (more than $60 \%$ of respondents). Thus, teachers have to search for new platforms and resources, to use their PCs and laptops in a more productive way, digging into technical issues of programs and resources. They happened not to be ready for such a challenge. Many of them do not have modern computers, which meet the latest re- 
quirements, at home; and using smartphones is not convenient and appropriate in some cases.

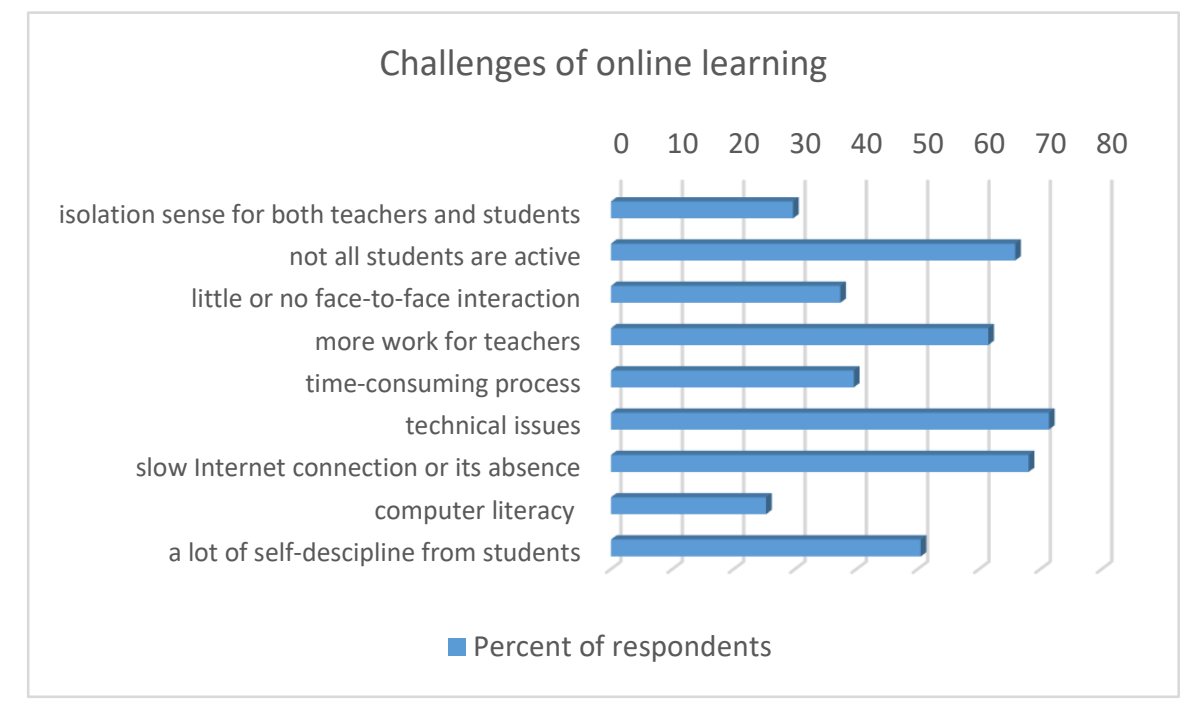

Fig. 6. Main challenges of online learning

It triggered the professional overload of teachers, who had to spend more time solving these issues and organizing the teaching process. They had to monitor the online collaboration of students, motivating them to study material in a new way; to check both online and written tasks; to change the format of tasks in general.

Respondents also mentioned the passivity of some students who did not enter online conferences and meetings, pointing to problems with the Internet, availability, and free access to computers. Such students demonstrated an unwillingness to study and waited until the last moment to complete obligatory tasks provided by teachers. As a result, they explained such behavior by the lack of face-to-face communication when they could interact with teachers in a direct way and feel their real support (almost $38 \%$ of respondents).

Being an innovative feature of the educational process for more establishments, online education required additional time, which was not stated in the workload of teachers. It provoked a certain level of discomfort and fatigue (almost $40 \%$ of respondents). As a result, more than $70 \%$ of teachers answering the question about time spent preparing and checking tasks for online classes gave a positive response. The same amount of time is spent by more than $18 \%$ of respondents. Moreover, less than $5 \%$ of teachers mentioned that they spent less time working online.

However, in general, teachers demonstrated readiness to implement the features of online education in their regular teaching process (Fig. 7) after some modifications and improvements. Only $15 \%$ of respondents spoke out against this form of learning and wanted to continue in a normal and habitual way. 


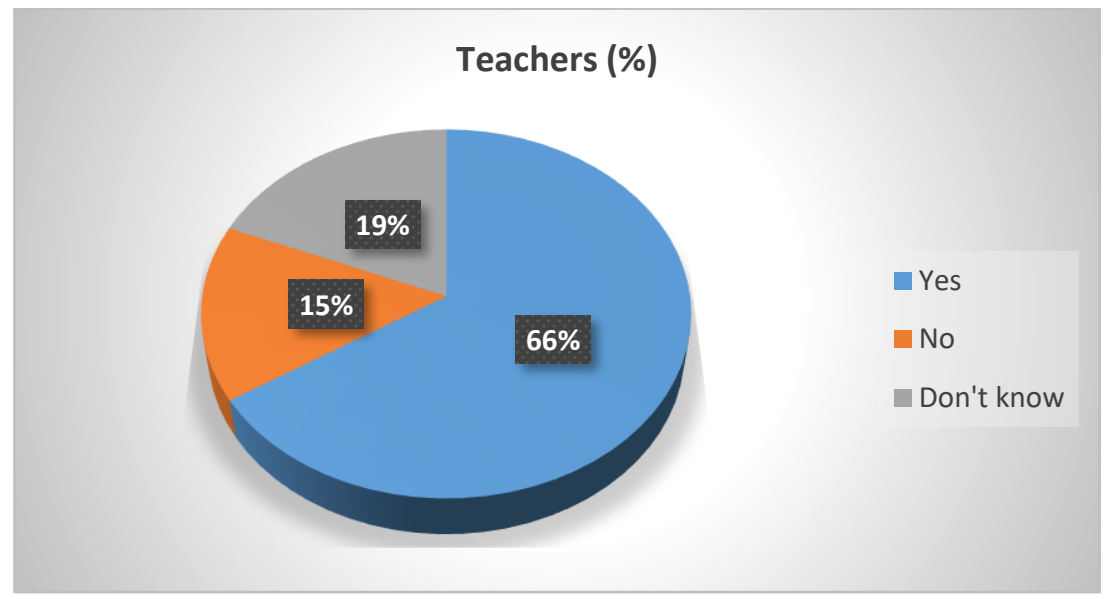

Fig. 7. Teachers' willingness to implement online learning in a regular teaching process

In comparison, according to the survey conducted by the Center for Teacher Education Research of Beijing Normal University [journals.sagepub.co], 70.5\% of teachers from China supported the adoption of online teaching, although more than $90 \%$ of respondents identified the need to have more access to online curriculum resources and cases of "successful cases of online teaching."

At the same time, students are not so positive about online education as teachers. Based on the survey results, they are not sure if they want to continue working online. Though about $49 \%$ of students liked online education, the other $51 \%$ were not so positive: more than $15 \%$ did not like it; about $27 \%$ were neutral and indifferent, and more than $8 \%$ could not understand such a form of learning.

\section{Discussion}

The educational process is undergoing great changes during a pandemic. Although the impact of ICT has already been a key determinant in its organization, a global crisis caused by COVID-19 led to a redistribution of priorities and changes in its framework. Both teaching and learning processes moved to a virtual space, changing their forms. Global lockdown, quarantine measures, and efforts to fight against the global pandemic are emphasized to be key factors for developing and improving features of the online educational process. The stated above demands a thorough analysis, scientific research, and verification of a set of hypotheses.

During the analysis, the second, the third, and the fourth hypotheses were confirmed, while the first one was disproved. It is important to note that the second hypothesis needs some clarifications to be fully approved. Thus, though the online form of education is a universal type of teaching and learning, groups should be organized according to the age of students. The younger the students, the fewer students should be in a group. Based on the survey, the optimal number of students for efficient and 
productive cooperation is $10-15$ people. Big groups of students are more appropriate for adults. Besides, it is mostly used for lectures than practical classes.

Dwelling on the advantages and challenges of online education during a global crisis, data proved that, in general, there were more positive aspects than negative ones. Most of the challenges were of technical or organizational character. They did not depend on educators and could be overcome by providing certain regulations at the national level or at the level of educational establishments.

The first hypothesis was disapproved due to the fact that world educational establishments demonstrated a low level of readiness for shifting the educational process to the virtual environment. Respondents mentioned a lack of standards for all institutions that should be used for teaching online. In spite of the variety of online resources and platforms, it was difficult to coordinate the work and find the appropriate form. Besides, the technical characteristics of platforms of many educational establishments failed to cope with the workload during a global lockdown.

Taking into account the information stated above, the aim of the article indicated at the beginning of the research was achieved. The key value of the article is the provision of a coherent and comprehensible framework of transformations in the educational process due to shifting online, its advantages, challenges, and certain improvements. However, some limitations in the application of the results can be outlined. Though the respondents represent a wide range of world countries, some of the countries are still not covered. Besides, there is no strict separation of higher, primary, and secondary educational establishments. It is appropriate to study independently all aspects of online education implementation in each of these institutions. At the same time, the stated limitations do not reduce the scientific and practical value of the article, outlining the further directions of the research.

\section{Conclusion}

The impact of the COVID-19 pandemic has led to visible and significant changes in the educational process. The main tendency is shifting priorities from face-to-face education to online teaching and learning. The letter means the wide implementation of technology tools in the process of education. Rapid transformations proved to have both positive and negative aspects in terms of cooperation between teachers and students as well as the framework of holding classes online.

The article has provided a thorough analysis of transformations happening in the educational process, namely, its adoption of online education forms. It has also reflected on attitudes of teachers from different world countries related to the conditions they have to work in, positive aspects and challenges of online learning and teaching, their own readiness and readiness of their establishments to start working online, as well as their willingness to implement such a form of education in the future. In addition, various technical resources for delivering lectures and holding classes online have been outlined and compared. In practical terms, the results and conclusions of the article are crucial for analyzing a general picture of tendencies in online education among educators as well as for developing measures on improving the means of the 
online educational process. The data revealed problems and shortcomings in the current situation of the educational transformation process due to the COVID-19 pandemic. It points to the feasibility of conducting scientific studies in this area.

Based on the results of this research, the perspectives of the further study are the development of a set of actions aiming at improving the online process of teaching and learning and comprehensive analysis of platforms and technological resources for secondary and higher education.

\section{References}

[1] Epignosis LLC (2014). E-learning: concepts, trends, applications. United States of America, San Francisco: Epignosis LLC.

[2] Means, B., Bakia, M., Murphy, R. (2014). Learning Online: What Research Tells Us about Whether, When and How. New York: Routledge. https://doi.org/10.4324/9780203095959

[3] Kopp, M., Gröblinger, O., Adams, S. (2019). Five common assumptions that prevent digital transformation at higher education institutions. $13^{\text {th }}$ International Technology, Education and Development Conference (INTED 2019), Valencia, Spain. https://doi.org/10.21125/inted.2019.0445

[4] Hodges, C., Moore, S., Lockee, B., Trust, T., \& Bond, A. (2020). The difference between emergency remote teaching and online learning. Educause Review, March 27, 2020. [Online]. Available: https://er.educause.edu/articles/2020/3/the-difference-betweenemergency-remote-teaching-and-online-learning [Accessed: Jan. 14, 2021]. https://doi.org/10.3390/soc10040086

[5] Manfuso, L.G. (2020). How the remote learning pivot could shape Higher Ed IT. EdTech Magazine. [Online]. Available: https://edtechmagazine.com/higher/article/2020/04/howremote-learning-pivot-could-shape-higher-ed-it [Accessed: Jan. 14, 2021].

[6] Unesco (2020). Distance learning solutions. [Online]. Available: https://en.unesco.org/ covid19/educationresponse/solutions [Accessed: Jan. 14, 2021].

[7] The World Bank (2020). How countries are using edtech (including online learning, radio, television, texting) to support access to remote learning during the COVID-19 pandemic. [Online]. Available: https://is.gd/r1JSQW [Accessed: Jan. 14, 2021]

[8] Zhou, L., Wu, S., Zhou, M., and Li, F. (2020). School's Out, But Class' On', The Largest Online Education in the World Today: Taking China's Practical Exploration During The COVID-19 Epidemic Prevention and Control As an Example. Best Evidence of Chinese Education, 4(2): 501-519. https://doi.org/10.2139/ssrn.3555520

[9] Allen, T. D., Eby, L. T., Poteet, M. L., Lentz, E., \& Lima, L. (2004). Outcomes associated with mentoring protégés: A meta-analysis. Journal of Applied Psychology, 89: 127-136. https://psycnet.apa.org/doi/10.1037/0021-9010.89.1.127. https://doi.org/10.1037/0021-90 10.89.1.127

[10] Shachar, M., \& Newmann, Y. (2003). Differences between traditional and distance education academic performances: A meta-analytic approach. The International Review of Research in Open and Distributed Learning, 4(2): 1-20. https://doi.org/10.19173/ irrodl.v4i2.153.

[11] Khadijah, M., Kainat, J., Mahwish, A., Ahsan, S. (2020). Advantages, Limitations and Recommendations for online learning during COVID-19 pandemic era. Pakistan Journal of Medical Sciences, 36 (COVID19-S4): 27-31. https://doi.org/10.12669/pjms.36.covid19$\underline{\mathrm{s} 4.2785}$ 
[12] Song, H., Wu., J., Zhi. T. (2020). Online Teaching for Elementary and Secondary Schools During COVID-19. ECNU Review of Education, 3(4): 745-754. https://doi.org/10.1177/ 2096531120930021

[13] Pant, A. (2014). Distance Learning: History, Problems and Solutions. Advances in Computer Science and Information Technology (ACSIT), 1(2): 65-70.

[14] Fojtík, R. (2018). Problems of distance education. ICTE Journal, 7(1): 14-23. https:// doi.org/10.2478/ijicte-2018-0002

[15] Levy, Y. (2007). Comparing dropouts and persistence in e-learning courses. Computers \& Education, 48(2): 185-204. https://doi.org/10.1016/j.compedu.2004.12.004

[16] Hrastinski, S. (2008). Asynchronous and synchronous e-learning. Educause Quarterly, 31 (4): 51-55.

[17] Peechapol Ch., Na-Songkhla J., Sujiva S. (2018). Development of Smartphone Application Based on the Theory of Planned Behaviour to Enhance Self-Efficacy for Online Learning. International Journal of Interactive Mobile Technologies. 12 (4). https://doi.org/10.3991/ ijim.v12i4.8715

[18] Liu Z.-Y., Lomovtseva N., Korobeynikova E. (2020). Online Learning Platforms: Reconstructing Modern Higher Education. International Journal of Interactive Mobile Technologies. 15 (13). https://doi.org/10.3991/ijet.v15i13.14645\%0d. https://doi.org/10.3991/ijet. $\underline{\mathrm{v} 15 \mathrm{i} 13.14645}$

[19] Farcas D., Reininger M. (2010). Distance Education in the Form of E-Learning in Chile: Training Human Capital for the 21st Century. International Journal of Interactive Mobile Technologies. 3 (3). https://doi.org/10.3991/ijac.v3i3.1372

[20] ZOOM (2020). A Message to Our Users. [Online]. Available: https://blog.zoom.us/amessage-to-our-users [Accessed: Jan. 14, 2021].

[21] Molla, R. (2020). Microsoft, Google, and Zoom are trying to keep up with demand for their now free work-from-home software. VOX. [Online]. Available: https://is.gd/h2urzc [Accessed: Jan. 14, 2021].

\section{$7 \quad$ Authors}

Ganna Khatser is Ph.D. in Philology, Associate Professor, The Department of English Translation Theory and Practice, Zaporizhzhia National University, Zaporizhzhia, Ukraine.

Maxim Khatser is Ph.D. in Economics, Associate Professor, The Department of Entrepreneurship, Management of Organizations and Logistics, Zaporizhzhia National University, Zaporizhzhia, Ukraine.

Liudmyla Bukharina is Doctor of Science (Economics), Professor, Head of the Department of Entrepreneurship, Management of Organizations and Logistics, Zaporizhzhia National University, Zaporizhzhia, Ukraine.

Yana Dybchynska is Ph.D. in Philology, Associate Professor, Head of the Department of Business Communication, Zaporizhzhia National University, Ukraine.

Lysenko Maryna is Ph.D. in Economics, Associate Professor, The Department of Entrepreneurship, Management of Organizations and Logistics, Zaporizhzhia National University, Zaporizhzhia, Ukraine.

Article submitted 2021-01-22. Resubmitted 2021-03-02. Final acceptance 2021-03-03. Final version published as submitted by the authors. 